\title{
The Management and Administrative Practices Resulting in the Exit of Nurses from the Irish Healthcare System - a Review
}

\author{
Syed A. Jilani \\ Postgraduate \\ Department of Business, Dublin Business School \\ Dublin, Ireland
}

(C) Syed A. Jilani. This work is licensed under the Creative Commons AttributionNonCommercial-ShareAlike 4.0 International License. To view a copy of this license, visit https://creativecommons.org/licenses/by-nc-sa/4.0/ .

\section{Abstract}

The exit of nurses from the Irish healthcare system is a growing concern especially coupled with the ageing population of Ireland. The article explores the many reasons nurses are leaving the country: mainly the disrespect by management, unfair compensation and the shortage of staff leading to professionals being overworked and eventually experiencing burnout. For many professionals, it has become an issue of their own physical and mental well-being. There are a few recommendations discussed to solve the issue of nurses, which includes a strong push to change perspectives of management and a change of policy by the government. These include retraining healthcare management, an emphasis on hiring and retaining nurses by increasing incentives and making the workload easier to carry.

Keywords: Nurses; Irish Healthcare; Healthcare Management.

\section{Introduction}

There is a critical demand for nurses and allied healthcare staff in most of the western world including the Republic of Ireland and the reason behind this current crisis is the scarcity and turnover of skilled and trained nurses, not only in the region but also at a global level (Hayes et al., 2006; Haddad and Toney-Butler, 2019). There is an imbalance between the skilled staff supply and rising healthcare demands all around the globe (World Health Organization (WHO), 2018). According to WHO (2018), nurses and midwives represent more than $50 \%$ of the current shortage in the health sector. In the current scenario recruitment and retention of nurses is a critical issue across the world including the Irish healthcare system, both in the public and private healthcare organisations.

The Irish healthcare system is currently facing a multitude of problems from low capacity in hospitals, extremely long wait times, how expensive it can be for someone to receive healthcare, etc. However, one that might shake the core of the Irish healthcare system is the rapid and steady exit of nurses and medical professionals. Approximately 14,000 Irish qualified nurses and midwives have chosen to leave the Irish healthcare system since 2010 (MacNamee, 2017). This figure comes from the 
number of verification certificates handed to these professionals, certificates that are used to prove appropriate qualification to foreign recruiters. The figure amounts to nearly 2,000 professionals every year. In this article, the issue of health professionals' retention, especially of nurses and midwives, in Ireland is highlighted. A thorough literature review and analysis of both the quantitative and qualitative research publications have been done to get a panoramic view of the diverse perspectives and issues that exist between the intricate layers of this multifaceted dilemma of nurses burnout, turnover, and hence leading to a shortage of mainly "womanpower" in this sector.

\section{The Irish Healthcare System}

The Irish healthcare system is a blend of public health services provided and funded by the government and private healthcare services provided on the basis of selffinancing or insurance (Goldrick-Kelly and Healy, 2018). Both the public and private healthcare services work differently and so the services offered to the patients differ in quality (Connolly and Wren, 2017). The private patient gets faster treatment as compared to the public patient, plus it is unaffordable for the large section of the population (Schneider and Devitt, 2018). About $€ 16.2$ billion is allocated for health in the 2018 budget which is 19\% greater than the $€ 13.6$ billion of 2013 (Connors, 2018).

The Irish health system is a mix of both public and private institutions and funders. It is primarily tax-financed and around $43 \%$ of the population has private health insurance (Connolly and Wren, 2019). The Irish health service has recently come through a radical reform program called 'Sláintecare' and is going through bedding down the process (Burke et al., 2018). 'Sláintecare' is a ten-year plan, proposed in May 2017, for healthcare delivery in Ireland with various reforms agreed upon by all political sectors. There are various components of this plan including 'Acute Care', 'Patient Safety', 'Health and Brexit' and 'Nursing and Midwifery' among others (Department of Health, 2016). The significant interest shown by the government in the health services sector in recent years may lead to major changes and aims to provide universal healthcare in Ireland (Keegan et al., 2019). The focus has now moved to consolidation and improved quality and efficiency. Every resident of Ireland is eligible for health and social services and, through Sláintecare, strategy services are accessible on a need basis rather than affordability.

\section{Ageing Population}

Results from the Census 2016 (Central Statistics Office, 2017), show that the population of Ireland is continuing to increase, although at a slower rate than in previous years. There is about a 1.9 million increase in the last 60 years. Over the past 15 years, the birth rate in Ireland has increased by 10.4\% from 57,854 in 2001 to 63,841 in 2016. Significantly, though, results show that the number, as well as the proportion of the population in the older age groups, is increasing rapidly. The number of people aged over 65 years has increased by approximately $19.1 \%$ since 2011 (Central Statistics Office, 2017). The total number of people over the age of 65 is increasing every year and it will be doubled by 2050. Population predictions state that 
the population over 65 will more than double over the next 30 years (Central Statistics Office, 2017), with evident implications for health service planning and delivery. With an ageing population at hand and a severe shortage of nurses, the consequences could be detrimental to the healthcare delivery system in Ireland.

\section{The Problem of Recruitment and Retention in the Irish Healthcare System}

In 2008, Ireland was hit hard by the economic recession that led to great levels of emigration, higher than countries like Spain or Greece. This led to a major brain drain and a problem that was just starting (Glynn, Kelly and MacÉinrí, 2013).

The WHO Global Code of Practice on the International Recruitment of Health Personnel recommends that each country must educate, retain and sustain an appropriate health workforce to develop sustainability in the healthcare system (WHO, 2010). While Ireland seems to excel in the education part of the equation by providing appropriate medical training and educating sufficient numbers (Humphries et al., 2011) it seems to be lacking in the retention of these nurses. This is leading to mass emigration and a continued shortage of nurses to staff the healthcare system.

A drastic impact of nursing staff shortage is inadequate care offered to patients leading to patient management at risk. Senior nurses are more involved in administrative and managerial tasks. As a result, they have little time for supervision of newly-qualified or contingent workforce. Modifications and restructuring of the healthcare service delivery such as the preference for day-care procedures, minimising the hospital stay for acute and emergency cases, the use of highly sophisticated technology, the rapid turnover of patients have further affected the workplace situation negatively. The cumulative effect of all of these determinants cause burnout in healthcare staff, and frustration and dissatisfaction in patients (Carayon and Gurses, 2008).

The major issue in Irish healthcare system delivery instability is increased emigration of Irish trained and qualified nurses and their replacement by foreign qualified staff. The main reason behind this brain drain of local qualified staff is unmanageable workplace situations leading to burnout and stressful life (Brugha, McAleese and Humphries, 2015). According to the Irish Nurses and Midwives Organisation (INMO), the working environment for nurses in Ireland is unsustainable and unsafe due to excessive workload, inadequate remuneration and lowering of morale. The INMO survey reveals that $71 \%$ of nursing graduates consider leaving Ireland (Thomas, 2019). A qualitative study was performed in 2015 through an online survey and found out the views of emigrated nurses, midwives, and doctors (Humphries et al., 2015). In most of these cases, the emigration destination was either Australia, UK, USA or Canada and it is reported that approximately 20,000 registered Irish nurses have relocated to foreign countries between 2007 and 2017 (Christensen, 2019). They found comparable differences in the working conditions and relocation packages offered to them between the source country and destination country. According to Peter Hughes of the Psychiatric Nurses Association (PNA), the Health Service Executive (HSE) started a campaign with the notion "Bring Them Home" in 2015 by offering them a token of $€ 1,500$ after completing a year of service in Ireland. This is 
highly comparable with the relocation package of $€ 8,000$ to $€ 9,000$ offered by the UK to foreign-trained nurses (Scott, 2019).

According to MacNamee (2017), the Irish Medical Organisation (IMO) and Irish Nurses and Midwives Organisation (INMO) has reported that this was long coming. Liam Doran, who held the position of General Secretary of the INMO, believes that the members of his organisation are disrespected by management and morale is low, being described as one of dejection. He says that many members are expected to work more with fewer resources which is leading to burnout and lost hope and this is the reason for the mass exit. Doran also mentions that hospital management and even the Department of Health has failed to protect and value their staff. Dr Peadar Gilligan, in an interview for an article for the Irish Times, said that the medical profession was under attack and medical professionals were sick of the so-called reform (Wall, 2018).

Irish nurses are highly sought after as they complete a four-year program with a widely recognised degree whereas most countries have three-year courses. The UK is offering Irish nurses' same levels of pay, better bonuses and working hours, according to Doran in his interview for MacNamee (MacNamee, 2017).

Brexit is a very important factor to consider in this whole scenario as it will have major effects on both countries' healthcare systems. In an article for the Brexit Institute, the effects of Brexit on the Irish Healthcare System were evaluated and it was found that recruitment and retention of staff by Ireland will likely be harder, as Irish trained nurses will have free access to work in the UK and there will be a need in the UK to replace EU and non-EU nurses (Staines, 2018).

\section{An Analysis of Management and Administrative Practices}

There are various factors that lead to this shortage crisis and some of them are: ageing of the workforce, inclination towards part-time opportunities, inadequate replacement of retiring nurses by fresh graduates, increased mobility of nurses within the country or overseas offering profound incentives. Since 2012, approximately 60,000 registered nurses who reached the age of 50 and above left the workforce and it is estimated that by 2020 nearly the same number will be retiring annually, resulting in immense loss of knowledge and prowess (Buerhausus, Auerbach and Staiger, 2017). The replacement of these senior and highly-experienced nurses with newly-graduated nurses is not uniform and steady. This imposes a challenge for healthcare organisations to create a balance between the exit of experienced staff and replacement by novice staff. A smooth and steady recruitment strategy will help in the transfer of knowledge and expertise from seniors to juniors.

Job stress and dissatisfaction, premature retirement, organisational injustice, and use of agency staff are some other determinants of enhanced healthcare staff turnover and interstate or overseas mobilisation, and hence creating vacant spaces to fill (McHugh et al., 2011; Aiken et al., 2013). Locum and temporary staffing by employing agency nurses are causing a negative impact on the quality of care services and adding more pressure and stress on the permanent staff as the contingent workers are not fully acquainted with the environment, policies, communication technology, 
personnel and other working elements of a particular healthcare organisation and need close supervision by the senior staff, orientation, and training to adapt well to a new working environment (Bray, 2019). In addition, it is an extra burden on the health budget as the agency staff, as compared to permanent staff, is far more costly (Dall'Ora C and Griffiths P, 2018). It has been reported by the HSE that an average of $€ 900,000$ a day on agency staff in hospitals and community healthcare organisations has been spent in the first five months of the year 2019 (Bray, 2019). Float pools or internal nursing which refer to available resources at the hospital level is more preferred than external arrangements with agencies as this is more cost-effective and safer in terms of patient safety and care (Hurst and Smith, 2011; Kortbeek et al., 2015). The float pool concept is used since 1981 and is widely applied and appreciated in a healthcare setting to overcome staffing deficiencies (Straw, 2018). A 'float pool' of nurses is a group of talented and highly-skilled supplemental nurses created or designed to be able to work in multiple units. This is a more applicable solution for healthcare managers to consider while tackling with staff shortages. This strategy has many benefits such as providing safe and quality care to critical patients, reduced job stress, and cost-effectivity (Rainess et al., 2015).

There is an increasing trend found in young nurses to prefer to work through an agency rather than a permanent or contractual commitment. The flexibility of shifts with lifestyle adjustments, more attractive remuneration and less stress of the job commitment and security, profound opportunities for personal development through continuous training and courses, are some of the reasons behind this 'shift' of employment pattern (Epstein, 2002).

There is evidence that Ireland is lacking in routine monitoring of the healthcare professional emigration crisis (Buchan et al., 2014). While there is some talk of the issue, whether it is national media highlighting the issue or policy-makers vowing to take action, there still seems to be a huge gap in research about the topic and there is a lack of evidence about the root cause of emigration.

The first step to solving this issue is identifying and studying the root causes of the problem. Is the crisis a direct result of the recession or cuts in cost by the Department of Health? Or is this a gradual build-up of frustration and loss of hope in the Irish healthcare system? (Thomas et al., 2013). The recession in Ireland led to many reductions in salary and a rise in tax (Thomas et al., 2013). It is important to realise how important a factor the economic recession was in this crisis. Oulton finds that healthcare management has often failed to recognise and solve problems that have bothered nurses for a long time such as longer working hours, insufficient training, inadequate staffing levels and salaries (1998). In MacNamee (2017), John Duddy, who was then president of the IMO and a neurosurgeon at Cork University Hospital, also agreed that poor management is one of the major reasons for this mass exit. He gave examples of nurses having to queue upwards of 45 minutes to try to find a parking spot. He went on further by saying that nurses would go up frequently to management with ideas on improvement in service, but these suggestions were completely ignored by management. A research study conducted to identify the causes of nurses' turnover intention and emigration found five main reasons reported by respondents which included working conditions, training opportunities, financial reasons, career progression and personal reasons (Humphries et al., 2015). 
The research found that nurses and midwives, particularly, felt that the low compensation and working conditions in Ireland forced them to leave (Murray, 2019). Professionals who worked in the emergency department felt there was no pattern for their days off and it was impossible to have a work-life balance as it was very difficult to plan events as they never knew when their days off might be. The research also found that respondents were so exhausted from their working days that their days off were spent recovering from the exhaustion. Respondents even noticed that there were detrimental effects of these working conditions on their own health and well-being, one reporting that they ended up in hospital twice because of the long hours and understaffing.

Respondents reported that they felt that management and employers had no respect for their employees or poor working conditions. Nurses noted that the emigration decision was not about money but the disrespect in the field. An article published in the Irish Examiner on 16 June 2018 reveals worrying statistics. It brings to light the increase of physical, verbal and sexual attacks on hospital nurses over the years. There were 559 recorded assaults in 2016 and 587 in 2017. These assaults are recorded in the HSE's National Incident Management System which is set up to record all assaults on health workers. However, the INMO said that these figures are even bigger in reality as assaults on nurses who work in voluntary hospitals in the country are not logged at all. These assaults are often career-ending and, in most cases, have traumatising and long-lasting effects on the nurses. Not much has been done to alleviate this problem. This shows our nurses that they, and the service they provide, are not valued or respected (Irish Examiner, 2018)

Caoimhe O'Brien, 27, a nurse from Dublin who, in an interview for the Irish Mirror, said that she became a nurse after four years of studying hard and going through 80 hours a week on work placements, for which she was paid less than minimum wage. Caoimhe was attacked by a patient while working over Christmas and has suffered from insomnia and anxiety since. She went on strike for the nurses stressing that nurses really had no choice but to strike as staffing levels are extremely dangerous, the workload is constantly increasing, and it is causing a lot of stress and burnout in nurses. This means that patient care is also affected (Hughes, 2019).

Nurses and midwives also echoed their medical colleagues and reported poor working conditions, understaffing and disrespect. They also noted their dissatisfaction against the introduction of the graduate nursing scheme which aims to recruit entry-level nurses at reduced rates of pay. All respondents called for an end to the scheme. They also expressed concerns for patient safety and believe that, because of the immense pressure on nurses due to shortages and long hours, it often became very difficult to exhibit safe practice (MacNamee, 2017).

\section{Recommendations}

Workforce planning is critical in terms of attracting and retaining qualified nursing staff in the field as over a period of time the pool is declining in number because of inadequate replacement by fresh graduates and ageing of the already working force (Haddad and Toney-Butler, 2019). A long-term solution to fill the shortage gap is to motivate and attract a new generation towards this profession, not only females but 
males as well, by offering them good job opportunities and incentives once graduated. Nursing is thought to be a female profession and only a few men opt for this profession (Sullivan, 2001). It has been found that across the western world the nursing profession is dominated and overpowered by women. The female to male nurse ratio among these countries is $10: 1$, specifically in Ireland only $7.8 \%$ of the total nurses are male (O'Connor, 2015).

According to Wall (2017), the Minister of Health has launched a new framework "to support the recruitment and retention of the right mix of staff across the health and social care system and build a sustainable, resilient workforce for the future". He said that through this new framework Ireland would be taking steps to build a more resilient and sustainable health workforce for the future. The objectives of the framework include the identification, agreement, and implementation of appropriate solutions for all challenges the nurses are facing (Wall, 2017). Dr Arne Björnberg, the Chairman of the Health Consumer Powerhouse, mentioned that healthcare systems reform revolves around demanding better management results and taking the politics out of healthcare (Ní Aodha, 2017). He suggests motivating staff, maximising production, minimising costs and continually monitoring outputs of reforms in healthcare.

Brugha, McAleese and Humphries (2015) found what it would take for these emigrant nurses to come back to Ireland. Their respondents felt that a significant improvement in the working conditions was crucial prior to their return. The most common reforms cited by respondents included better working hours, task shifting or transfer of tasks, support by senior colleagues, structured teaching and training, better pay, respect, more consultants, computerised health records, etc. Staffing levels were cited as a very important reform that highlighted the need for an increase of front-line staff, improving nurse to patient ratios, adequate holiday covers, etc.

Research done previously has shown that retention is proven to be a better solution to recruitment when dealing with staffing shortages (Halter et al., 2017). Doran suggests that it is time for the concerned authorities to work on keeping Irish nurses in Ireland and in the public sector. He highlights the issue of the substantial pay gap between nurses working in the public and private sector, the latter being paid substantially more. He suggests that every final year nursing student is offered a permanent job, along with a shift in attitude towards nurses already in the field, providing them with more respect and job security (MacNamee, 2017). Steps should be taken to ensure that their demands are heard and worked on rather than ignored.

One of the recruitment strategies which can improve the situation of this shortage and retention challenge is to attract foreign qualified nurses from abroad and introduce training programs for them especially for critical shortage areas like intensive care units, midwifery, and aged care (Allen, 2019). Bridging courses for overseas qualified nurses and midwives should be arranged by public and private Irish healthcare organisations so that they can reach the Irish healthcare services standard. These locally trained overseas qualified staff should then be retained by offering long-term temporary resident status while already in the state (Parliament of Australia, 2002). There is a significant contribution of foreign qualified registered nurses, mostly from India and the Philippines in the Irish healthcare sector since 2000 and further planning and policy implementation is desired to retain this valuable talent (Humphries, Brugha and McGee, 2008). 
Another problem area is inappropriate or disproportionate skill mix. It should be taken care of that those new graduates or overseas staff should be a desired skill mix to fulfil the demands in specialist sectors like aged care, intensive care, community and mental health, midwifery, etc. (INMO, 2018). The WHO recommends that to overcome this challenge, devising an outstanding policy is obligatory and strong leadership with competent governance and effective execution at a higher organisational level is the need of the day (2019).

\section{Conclusion}

A shortage of nurses provides a massive strategic risk to the effective functioning of a healthcare system and it seems like the Irish healthcare system is facing a crisis with the mass exit of nurses.

To achieve medical workforce sustainability and to revert the emigration of highly qualified and trained staff strong strategic planning is mandatory. The areas to be more focused upon are improved and supportive working environment, revised job specifications and terms of service, organisational justice at all levels, equitable remunerations, opportunities and access to training and personal development and last of all, the most important factor of burnout which is to address is shorter and more convenient working shifts (Humphries et al., 2015).

It seems there is a lot wrong with the Irish healthcare system but not all hope is lost. The damage that has been done can still be undone and rectified. First, the emigrant health professionals are still interested in returning to Ireland if certain reforms are made (Humphries et al., 2015). There is still a window of opportunity for the Irish healthcare system. Secondly, it may not be as hard to introduce the reforms emigrant health professionals ask for, all the factors these professionals complain of are within the control of policymakers and management. If these were outside the control of the health system such as mass unemployment, recession, etc., this could be a difficult feat. However, with a few policy changes and a change in attitude, management can bring about changes to real concerns of nurses such as poor working conditions, understaffing, better pay, increase of respect and value.

Many articles reference the Minister of Health's speech at the annual conference of the IMO in Killarney in 2018. He suggested that even though the Irish Government plans to spend $€ 11$ billion additionally in hospitals and the system to boost capacity, it might not be the solution to the whole problem. Mr Simon Harris said in his speech: "We must make real changes to healthcare delivery in order to have a sustainable healthcare system in the future. Put simply, we have no option but to reform."

To attract back emigrant health professionals, the Irish healthcare system needs reforms and to implement working conditions and career progression opportunities that can compete with benefits and compensation packages offered by destination countries. This will not only help attract emigrant health professionals back but also be a major help in the recruitment and retention of potential health professionals. 


\section{REFERENCES}

Aiken, L. H., Shang, J., Xue, Y. and Sloane, D.M. (2013) 'Hospital use of agency-employed supplemental nurses and patient mortality and failure to rescue', Health Services Research, 48(3), pp. 931-48. doi: 10.1111/1475-6773.12018 (Accessed: 28 September 2019)

Allen, S. (2019) '2020 Global health care sector outlook', Deloitte. Available at: https://www2.deloitte.com/global/en/pages/life-sciences-and-healthcare/articles/globalhealth-care-sector-outlook.html (Accessed: 5 January 2020).

Bray, J. (2019) HSE agency spend hits $€ 900,000$ daily on agency staff. Available at: https://www. irishtimes.com/news/health/hse-agency-spend-hits-900-000-daily-on-agencystaff-1.3969987 (Accessed: 28 September 2019).

Brugha, R., McAleese, S. and Humphries, N. (2015) 'Ireland: a destination and source country for health professional migration'. Available at:

https://www.who.int/workforcealliance/031616-108IrelandStudy.pdf?ua=1 (Accessed: 2 September 2019).

Buchan, J., Wismar, M., Glinos, I.A. and Bremner, J. (eds.) (2014) 'Health professional mobility in a changing Europe', Observatory Studies Series No. 32.. Available at:

http://www.euro.who.int/ data/assets/pdf file/0006/248343/Health-Professional-Mobility-ina-Changing-Europe.pdf (Accessed: 2 September 2019).

Buerhausus, P., Auerbach, D. and Staiger, D. (2017) 'How should we prepare for the wave of retiring baby boomer nurses?', Health Affairs Blog. Available at:

https://www.healthaffairs.org/do/10.1377/hblog20170503.059894/full/ (Accessed: 30 November 2019).

Burke, S., Barry, S., Siersbaek, R., Johnston, B., Ní Fhallúin, M. and Thomas, S. (2018) 'Sláintecare - a ten-year plan to achieve universal healthcare in Ireland', Health Policy, 122(12), pp. 1279-1282. doi.org/10.1016/j.healthpol.2018.05.006 (Accessed: 30 November 2019).

Carayon, P. and Gurses, A. P. (2008) 'Nursing workload and patient safety - a human factors engineering perspective', in Hughes, R.G. Patient safety and quality: an evidencebased handbook for nurses. Rockville (MD): Agency for Healthcare Research and Quality. Available at: http://www.ncbi.nlm.nih.gov/pubmed/21328758 (Accessed: 28 September 2019).

Christensen, A. R. (2019) 'Nearly 20,000 nurses left Ireland between 2007 And 2017', Evoke.ie, 20 January 2019 [Online] Available at: https://evoke.ie/2019/01/20/news/irishnurses-left-ireland-last-decade (Accessed: 30 November 2019)

Central Statistics Office (2017) 'Census 2016 summary results - Part 1'. Available at: https://www.cso.ie/en/media/csoie/newsevents/documents/census2016summaryresultspart1 /Census2016SummaryPart1.pdf (Accessed: 29 September 2019).

Connolly, S. and Wren, M. A. (2019) 'Universal health care in Ireland - what are the prospects for reform?', Health Systems and Reform, 5(2), pp. 94-99. doi: 10.1080/23288604.2018.1551700 (Accessed: 29 November 2019). 
Connolly, S. and Wren, M. A. (2017) 'Unmet healthcare needs in Ireland: analysis using the EU-SILC survey', Health Policy, 121(4), pp. 434-441. doi: 10.1016/j.healthpol.2017.02.009 (Accessed: 28 September 2019).

Connors, J. (2018) 'Health budget oversight and management: alignment of health budget and National Service Plan', Available at:

http://www.budget.gov.ie/Budgets/2019/Documents/Health Budget Oversight and Management.pdf (Accessed: 2 July 2019).

Dall'Ora, C. and Griffiths, P. (2018) 'Effects of flexible staffing on patient outcomes and healthcare costs', Nursing Times, 10 April 2018 [Online]. Available at:

https://www.nursingtimes.net/roles/nurse-managers/effects-of-flexible-staffing-on-patientoutcomes-and-healthcare-costs-10-04-2018/ (Accessed: 28 September 2019).

Department of Health (2016) 'Strategy for the Office of the Chief Nursing Officer 2015-2017'. Available at: https://www.gov.ie/en/publication/8716ba-strategy-for-the-office-of-the-chiefnursing-officer-2015-2017/ (Accessed: 5 January 2020).

Epstein, A. (2002) 'NHS versus Agency: why nurses choose their work', Daily Mail, 30 January 2002 [Online]. Available at: https://www.dailymail.co.uk/health/article-97034/NHSversus-Agency-nurses-choose-work.html (Accessed: 28 September 2019).

Glynn, I., Kelly, T. and MacÉinrí, P. (2013) Irish emigration in an age of austerity. Cork: University College Cork. Available at:

https://www.ucc.ie/en/media/research/emigre/Emigration in an Age of Austerity Final.pdf (Accessed: 2 September 2019).

Goldrick-Kelly, P. and Healy, T. (2018) 'Equality in Irish healthcare - time for a new deal', Nevin Economic Research Institute Working Paper Series. Available at:

https://www.nerinstitute.net/research/equality-irish-healthcare-time-new-deal (Accessed: 30 November 2019).

Haddad, L. M. and Toney-Butler, T. J. (2019) 'Nursing shortage', StatPearls. Available at: http://www.ncbi.nlm.nih.gov/pubmed/29630227 (Accessed: 28 September 2019).

Halter, M., Pelone, F., Boiko, O., Beighton, C., Harris, R., Gale, J., Gourlay, S. and Drennan, V. (2017) 'Interventions to reduce adult nursing turnover: a systematic review of systematic reviews', Open Nursing Journal, 15 August 2017, 11, pp.108-123. doi: 10.2174/1874434601711010108 (Accessed: 28 September 2019).

Hayes, L. J., O’Brien-Pallas, L., Duffield, C., Shamian, J., Buchan, J., Hughes, F., Spence Laschinger, H. K., North, N., and Stone, P.W. (2006) 'Nurse turnover: a literature review', International Journal of Nursing Studies, 43(2), pp. 237-263. doi:

10.1016/J.IJNURSTU.2005.02.007 (Accessed: 29 November 2019).

Hughes, E. (2019) 'Dublin nurse, 27, who was attacked at work reveals why she's going on strike in powerful statement', Irish Mirror, 7 February 2019 [Online]. Available at: https://www.irishmirror.ie/news/irish-news/nurses-strike-ireland-pay-shortages-13964533 (Accessed: 1 December 2019).

Humphries, N., McAleese, S., Matthews, A., and Brugha, R. (2015) '"Emigration is a matter of self-preservation. The working conditions ... are killing us slowly": qualitative insights into health professional emigration from Ireland', Human Resources for Health, 13(1), p. 35. 
Available at: https://human-resources-health.biomedcentral.com/articles/10.1186/s12960015-0022-6 (Accessed: 1 December 2019).

Humphries, N., Tyrrell, E., McAleese, S., Bidwell, P., Thomas, S., Normand, C. and Brugha, R. (2011) 'A cycle of brain gain, waste and drain-a qualitative study of non-EU migrant doctors in Ireland', Human Resources for Health, 11. Available at: https://human-resourceshealth.biomedcentral.com/articles/10.1186/1478-4491-11-63 (Accessed: 1 December 2019)

Humphries, N., Brugha, R. and McGee, H. (2008) 'Overseas nurse recruitment: Ireland as an illustration of the dynamic nature of nurse migration'. Available at:

https://repository.rcsi.com/articles/Overseas nurse recruitment Ireland as an illustration of the dynamic nature of nurse migration /10776122 (Accessed: 18 June 2019).

Hurst, K. and Smith, A. (2011) 'Temporary nursing staff - cost and quality issues', Journal of Advanced Nursing, 67(2), pp. 287-296. doi: 10.1111/j.1365-2648.2010.05471.x. (Accessed: 18 June 2019).

Irish Nurses and Midwives Organisation (2018) 'INMO Survey on nursing/midwifery 4th Year students'. Available at: https://www.inmo.ie/Home/Index/217/13193 (Accessed: 2 December 2019).

Irish Examiner (2018) 'Attacks on nurses increase: zero tolerance is the answer', Irish Examiner, 26 June [Online]. Available at:

https://www.irishexaminer.com/breakingnews/views/attacks-on-nurses-increase-zerotolerance-is-the-answer-851023.html (Accessed: 30 November 2019

Keegan, C., Teljeur, C., Turner, B. and Thomas, S. (2019) 'Switching benefits and costs in the Irish health insurance market: an analysis of consumer surveys', International Journal of Health Economics and Management, 19(1), pp. 15-32. doi: 10.1007/s10754-018-9244-1 (Accessed: 2 September 2019).

Kortbeek, N., Braaksma, A., Burger, C.A.J., Bakker, P.J.M. and Boucherie, R.J. (2015) 'Flexible nurse staffing based on hourly bed census predictions', International Journal of Production Economics, 161, pp.167-180. doi: 10.1016/J.IJPE.2014.12.007 (Accessed: 28 November 2019).

MacNamee, G. (2017) 'Sick and tired': why Ireland's' nurses are leaving in their droves', the journal.ie, 14 January 2017 [Online]. Available at: https://www.thejournal.ie/irish-nursessick-and-tired-3181227-Jan2017/ (Accessed: 2 September 2019).

McHugh, M. D., Kutney-Lee, A., Cimiotti, J.P., Sloane, D.M., and Aiken, L.H. (2011) 'Nurses' widespread job dissatisfaction, burnout, and frustration with health benefits signal problems for patient care', Health Affairs, 30(2), pp. 202-210. doi: 10.1377/hlthaff.2010.0100 (Accessed: 2 September 219).

Murray, S. (2019) 'Nurses and midwives are striking this month. Here's how much they get paid', thejournal.ie, 12 January 2019 [Online] Available at: https://www.thejournal.ie/nursesmidwives-pay-4433076-Jan2019/ (Accessed: 28 November 2019).

Ní Aodha, G. (2017) 'Ireland's healthcare system: what exactly are we doing wrong?', thejournal.ie, 19 February [Online]. Available at: https://www.thejournal.ie/irish-healthcaresystem-3242479-Feb2017/ (Accessed: 2 September 2019). 
O'Connor, T. (2015) 'Men choosing nursing: negotiating a masculine identity in a feminine world', The Journal of Men's Studies, 23(2), pp. 194-211. doi: 10.1177/1060826515582519 (Accessed: 28 November 2019).

Oulton, J. (1998) 'International trade and the nursing profession' in: UNCTAD-WHO Joint Publication International Trade in Health Services. Available at:

https://unctad.org/en/docs/po8he98.pdf (Accessed: 2 September 2019).

Parliament of Australia (2002) 'Nurse shortages and the impact on health services' Available at:

https://www.aph.gov.au/Parliamentary Business/Committees/Senate/Community Affairs/Co mpleted inquiries/2002-04/nursing/report/c02 (Accessed: 28 November 2019).

Rainess, M., Archer, W., Hofmann, L. and Nottingham, E. (2015) 'Empowering float nurses', Nursing Management, 46(2), pp.15-19. doi: 10.1097/01.NUMA.0000460046.94309.d0 (Accessed: 28 November 2019).

Schneider, S. M. and Devitt, C. (2018) 'Accessing healthcare in times of economic growth and economic downturn: evidence from Ireland', Journal of European Social Policy, 28(4), pp. 357-369. doi: 10.1177/0958928717739240 (Accessed: 2 September 2019).

Scott, C. (2019) 'I'm earning twice as much in Australia, give me a reason to come home' Irish nurse in Sydney tells Leo', Extra.ie, 20 January 2019 [Online]. Available at:

https://extra.ie/2019/01/20/news/real-life/irish-nurses-abroad-australia (Accessed: 2

September 2019).

Staines, A. (2018) 'Brexit and the Irish health', Brexit Institute News, 2 May 2018. Available at: http://dcubrexitinstitute.eu/2018/05/brexit-and-the-irish-health-system/ (Accessed: 2 September 2019).

Straw, C. N. (2018) 'Engagement and retention in float pools: keeping the team above water', Nursing Management, 49(10), pp. 30-36. doi:

10.1097/01.NUMA.0000546201.01962.0d (Accessed: 28 September 2019).

Sullivan, P. (2001) 'Nurses decry profession's 1:19 male-to-female ratio', CMAJ: Canadian Medical Association Journal, 164(12), p. 1738. Available at:

https://www.ncbi.nlm.nih.gov/pmc/articles/PMC81172/ (Accessed: 28 September 2019).

Thomas, C. (2019) 'Now I can see that there will be nobody nursing me unless we start paying a salary for the job we do', thejournal.ie, 9 January 2019 [Online]. Available at: https://www.thejournal.ie/now-i-can-see-that-there-will-be-nobody-nursing-me-unless-westart-paying-a-salary-for-to-the-job-we-do-4429431-Jan2019/ (Accessed: 30 November 2019).

Thomas, S., Keegan, C., Barry, S., Layte, R., Jowett, M. and Normand, C. (2013) 'A framework for assessing health system resilience in an economic crisis: Ireland as a test case', BMC Health Services Research, 13(1), p. 450. doi: 10.1186/1472-6963-13-450 (Accessed: 28 September 2019).

Wall, M. (2018) 'We have no option but to reform' healthcare system, says Harris', The Irish Times, 7 April 2018 [Online]. Available at: https://www.irishtimes.com/news/health/we-haveno-option-but-to-reform-healthcare-system-says-harris-1.3454428 (Accessed: 2 September 2019). 
Wall, M. (2017) 'Shortages of skilled staff poses risk to health system, warns Department', The Irish Times, 14 November 2017 [Online] Available at:

https://www.irishtimes.com/news/health/shortages-of-skilled-staff-poses-risk-to-healthsystem-warns-department-1.3291832 (Accessed: 2 September 2019).

World Health Organisation (2019) 'Nursing and midwifery'. Geneva: World Health Organisation. Available at: https://www.who.int/news-room/fact-sheets/detail/nursing-andmidwifery (Accessed: 28 September 2019).

World Health Organisation (2018) 'Managing health workforce migration - The Global Code of Practice', Geneva: World Health Organisation. Available at:

https://www.who.int/hrh/migration/code/practice/en/ (Accessed: 29 September 2019).

World Health Organisation (2010) 'WHO global code of practice on the international recruitment of health personnel', Geneva: World Health Organisation. Available at: https://www.who.int/hrh/resources/code implementation/en/ (Accessed: 29 September 2019). 